\title{
The efficiency of public transport operations: An evaluation using stochastic frontier analysis
}

\author{
Johan Holmgren
}

\section{Linköping University Post Print}

\section{Tweet}

N.B.: When citing this work, cite the original article.

Original Publication:

Johan Holmgren, The efficiency of public transport operations: An evaluation using stochastic frontier analysis, 2013, Research in Transportation Economics, (39), 1, 50-57.

http://dx.doi.org/10.1016/j.retrec.2012.05.023

Copyright: Elsevier

http://www.elsevier.com/

Postprint available at: Linköping University Electronic Press

http://urn.kb.se/resolve?urn=urn:nbn:se:liu:diva-85804 


\title{
The efficiency of public transport operations - An evaluation using Stochastic Frontier Analysis
}

\author{
Johan Holmgren ${ }^{\mathrm{a}, *}$ \\ ${ }^{a}$ Division of Communications and Transport Systems, Department of Science and Technology, Linköping University, Sweden \\ * Department of Science and Technology, Linköping University, SE-60174, Norrköping, Sweden, +46 (0)11 363605 , \\ johan.holmgren@liu.se \\ Keywords: \\ Public transport \\ Cost \\ Stochastic frontier \\ Efficiency
}

\section{ABSTRACT}

The aim of this study is to evaluate the efficiency of public transport operations undertaken in Swedish counties by the public transport authorities (PTA), taking into account the substantial differences in operating conditions between counties. The analysis will be performed using stochastic frontier analysis (SFA) with annual data from 1986 to 2009 for 26 Swedish counties. The analysis shows how the efficiency of the individual counties has changed over time. The results are used to provide a ranking (in terms of efficiency) of the Swedish public transport authorities that can provide a basis for benchmarking. It is concluded that the efficiency of the public transport providers in all counties fell during the observed time period. Defining cost efficiency as the ratio of minimum cost to observed cost, the overall (average) cost efficiency for the industry fell from $85.7 \%$ in the eighties to $60.4 \%$ for the period from 2000 to 2009. Possible explanations for the development include increased emphasis on route density as well as higher environmental and safety requirements.

\section{Introduction}

In a time of increasing concern about global warming and other environmental problems, increased public transport usage is often advanced as part of the solution. In Sweden, as well as in many other countries, public transport is heavily subsidized and controlled by public authorities (Button, 2010). Subsidization and public control can be justified on theoretical grounds, for the optimal price level and structure result in financial deficits. In other words, left unregulated, the market would provide less public transport at a higher price than the optimal (i.e. social welfare maximizing) (Jansson, 1984, Small and Parry, 2009, and Ljungberg, 2010).

However, there is much evidence of what can be called regulatory failure, rather than market failure, in situations where the public sector provides a service itself or regulates an industry. 
Public officials do not always act in the best interests of the public. They may instead try to fulfil their own self-interest and/or be under the influence of interest groups (e.g. Buchanan and Tullock, 1962, Niskanen, 1971, and Mueller, 2003). It may also be that the industry they are operating within, or trying to regulate, is so complex that it is hard to process the information and actually find the optimal solution.

In a working market environment, firms operating inefficiently eventually disappear either because of competition or by being bought by someone able to increase their efficiency and thus increase profits. This is obviously not the case with public operations. However, in a time where many countries are in a fiscal crisis, there is increased concern about public sector deficits and the need for efficient use of public funds is apparent. The demand for public funds appears limitless and politicians are hard-pressed not to raise taxes or divert money from other deserving needs such as education, healthcare, childcare or eldercare. Thus it is important to continuously evaluate whether current public transport subsidies are being used optimally.

The aim of this study is to evaluate the efficiency of public transport operations undertaken in Swedish counties by public transport authorities (PTA), taking into account the substantial differences in operating conditions between counties. The choice of evaluating the PTAs in terms of efficiency is due to the fact that in the Swedish public system the PTAs makes the decisions on fares, network design, frequency and what kind of vehicles that are to be used etc. The operators actually driving the vehicles operates under gross contracts and have no influence over the design of the system. ${ }^{1}$ In terms of Macario (2001) the Swedish system can be characterized as one in which the authorities have almost all influence and initiative and the operators almost none. (see also Hansson, 2011, who discuss the dominant influence of the PTAs in the Swedish system. The analysis will be based on annual data from 25 Swedish counties $^{2}$ from 1986 to 2009. The results will be used to rank Swedish public transport authorities in terms of efficiency in order to provide a basis for benchmarking.

Efficiency can be defined and analysed in a number of ways. The theoretical foundation for two commonly used methods of analysis, data envelopment analysis (DEA) and stochastic frontier analysis (SFA), can be found in economic theories of production. Both DEA and SFA provide information on how economic agents transform inputs into outputs, i.e. they reflect different aspects of production technology. Briefly, DEA uses mathematical programming (non-parametric) methods to identify the highest output levels that can be obtained (or are obtained by the observed producers) by combining different inputs. In SFA a production function (or its dual, a cost function) is estimated using econometric (parametric) methods in order to identify the highest possible production levels that can be attained given the available production technology (or the lowest cost of providing a production level given the

\footnotetext{
${ }^{1}$ They of course influence performance of the system by being good or bad at keeping the time table set by the PTA, having drivers that are perceived as nice etc.

${ }^{2}$ As will be explained, changes in regional organisation in Sweden meant that some of these counties ceased to exist at some point during the observed time period.
} 
price of inputs used in the production process) (e.g. Färe et al.,1994, Coelli et al., 2005 and Bogetoft and Otto, 2010).

Both approaches have been applied to different parts of the transport sector. Recent applications of DEA to the performance of airlines can be found in Barbot et al. (2008), Barros and Peypoch (2009), Bhadra (2009), Ouellette et al. (2010), and Merkert and Hencher (2011). Examples of DEA applications to the rail industry can be found in Coelli and Perelman (1999), Rivera-Trujillo (2005) and Merkert et al. (2010). Recent applications of DEA to public transport operations include Odeck (2008), Söderberg (2009) and Hirschhausen and Cullmann (2010). Overviews of earlier results can be found in De Borger et al. (2002).

De Borger et al. (2002) also provide an overview of SFA applications to public transport operations. A more recent example of an application using a stochastic production frontier method is provided in Lin et al. (2011). Other examples of stochastic cost frontier applications can be found in Jørgensen et al. (1997), Dalen and Gomez-Lobo (2003), Piacenza (2006), Cambini et al. (2007), Karlaftis (2010) and Sakai and Shoji (2010). Cambini et al. (2007) also includes an overview of previous applications.

The present study will be based on an unusually long period of time in which the Swedish public transport sector underwent a series of important changes likely to affect performance. One of the most important was the movement from in-house provision of all services in 1986 to procurement through competitive tendering of almost all traffic by the end of the observation period (Hansson, 2010a).

\section{Public transport in Sweden}

In 1979 a major organizational reform of the Swedish public transport sector took place. It was a reform that since then has had a profound impact on the workings of the local and regional public transport system. It required a Public Transport Authority (PTA) to be established in each county. The PTA:s are most commonly owned by the municipalities and the county council jointly, and were up to the beginning of 2012 responsible for the coordination of public transport operations in the counties. (Act 1978:438) In 1985 the PTA:s were also given the responsibility of issuing licenses for operating public transport services within the county and in practice meant that they had the options of (1) performing the services themselves, in house, acting as an operator themselves or (2) contracting out the service to private companies. In this context, it should be mentioned that before the reform of 1979, public transport services were provided by a mixture of private and publicly owned firms. Before 1960 the sector was dominated by private companies operating without subsidies but increased costs and rising car ownership resulted in many of them being taken over by municipality owned companies during the 1960:s and 1970:s. These companies 
(including the municipally owned) all operated independently without coordination of fares and service. (Jansson and Wallin, 1991, Alexandesson, 2010)

The most important change 1979 was that the fares was coordinated and subsidized trough the PTA:s. (Jansson and Wallin, 1991, Alexandesson, 2010) After 1985, the PTA:s gradually started to implement competitive tendering of the operations. Figure 1 show the development of proportion of services subjected to tendering. Since then the proportion has around $95 \%$ with some municipalities still operating some special services and school transports themselves. (Alexandesson, 2010)

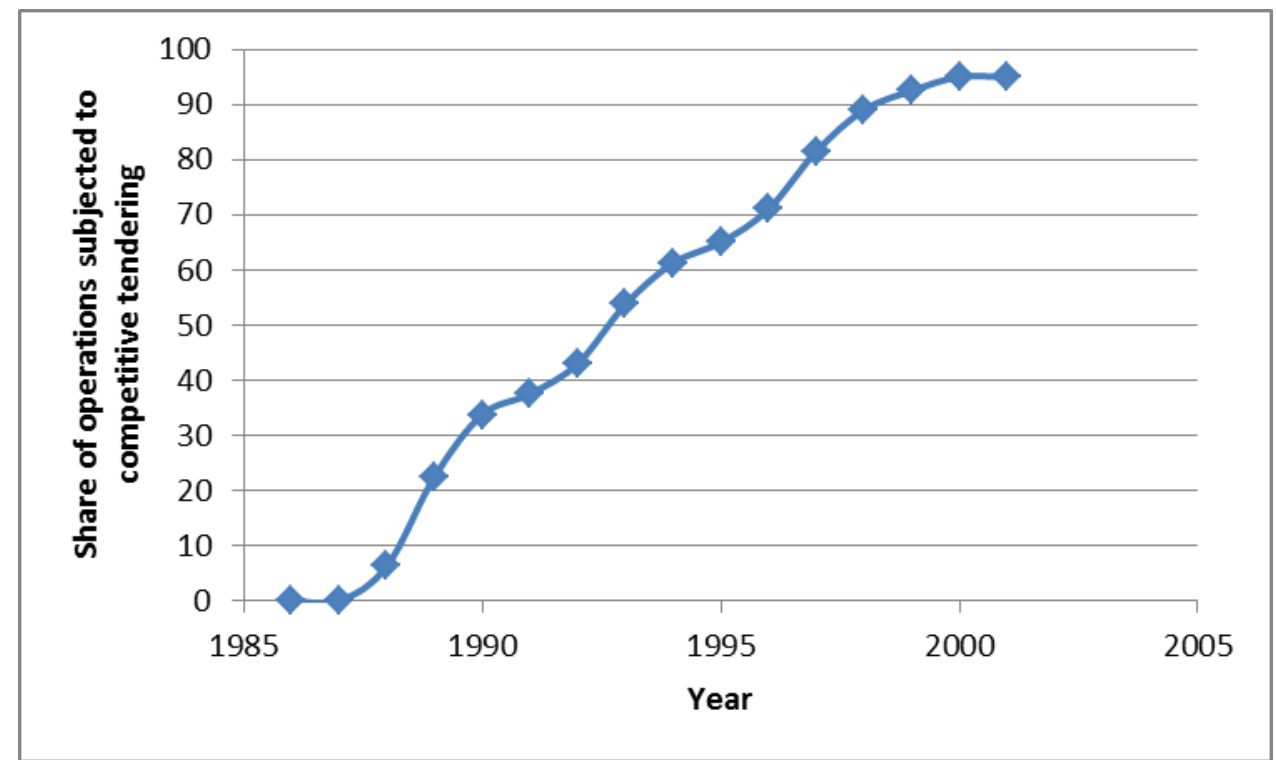

Figure 1. The proportion of local/regional public transport in Sweden subjected to competitive tendering. (Source: Alexandersson, 2010)

Despite relying on private companies to perform the actual operations, the PTA:s has retained all network planning as well as decisions on frequency and fares. They have also regulated what kind of vehicles that should be used and what standard they should have. The operators have worked under gross contracts with no influence over actual operations. (Alexandesson, 2010) It has been suggested that this might be a source of inefficiency in the system since the knowledge of the market held by the operators is not utilized in order to optimize services. (Sonesson, 2006) Alexandersson et.al. (1998) and Alexandersson and Pyddoke (2003) examine the effects of competition on the costs and draw the conclusion that although initial decreases in costs can be seen from tendering there is no evidence of any long run effects on costs. From 1986 to 2009 the average level of subsidy increased from $54 \%$ to $61 \%$. (For further descriptions and discussions on the organization of Swedish public transport se e.g. Hansson, 2010b)

\section{Cost Theory and Efficiency Analysis}

In general terms, the cost function shows the minimum cost of producing a given quantity of output from the available inputs. Costs are therefore expressed as a function of output level and factor prices, i.e. 
where $W$ is a vector of input prices and $Q$ is the level of output (or a vector of output levels if a multiple output technology is described). The cost function expressed in equation (1) is deterministic and assumes that operations are performed in an efficient (cost-minimizing) manner, which might not be the case in reality. Cost frontiers allow for the possibility of inefficiency in the operations of individual decision-making units:

$$
C_{i} \geq C\left(w_{1 i}, w_{2 i} \ldots \ldots . ., w_{N i}, q_{1 i}, q_{2 i}, \ldots \ldots . ., q_{M i}\right)
$$

where $C_{i}$ is the total cost for decision-making unit (DMU) $i$, using $N$ different inputs in the production of $M$ different kinds of output. Introducing $d_{i}$ as a measure of the inefficiency of decision- making unit i and a random disturbance term $\varepsilon_{i}$ results in:

$$
C_{i}=C\left(w_{1 i}, w_{2 i} \ldots \ldots . ., w_{N i}, q_{1 i}, q_{2 i}, \ldots \ldots . ., q_{M i}\right)+d_{i}+\varepsilon_{i}
$$

In the present case it is assumed that the PTAs use capital, labour and fuel in order to produce passenger trips. ${ }^{3}$ The total cost for public transport in county i during the year $t\left(C_{i, t}\right)$ is therefore determined by the number of trips made $\left(\mathrm{q}_{\mathrm{i}, \mathrm{t}}\right)$, the wages of bus drivers $\left(\mathrm{w}_{\mathrm{i}, \mathrm{t}}^{1}\right)$, the price of diesel fuel $\left(w_{i, t}^{2}\right)$ and the cost of capital $\left(w_{i, t}^{3}\right)$. The cost of capital is defined as the interest rate of ten-year government bonds. Nash (1982) and Button (2010) include general discussions on cost relationships in public transport production, while Oum and Walters (1996) provide a discussion on cost functions in transportation research.

Number of trips by all transport modes is used as the relevant output measure. ${ }^{4}$ The model (3) allows for the possibility to include multiple outputs and if data were available the number of trips made by different modes could be entered as different types of output if that was appropriate. Data is, however not available but it can be argued that this is not a problem since the relevant output measure actually is how many passengers that is transported (number of trips). To understand why this is so one has to ask what the purpose of operating a public transport system is. The purpose of a public transport system should be to provide mobility, hence meting the demand for transport in the region. The purpose is not to produce a specific amount of trips by bus, train, tram or subway. The choice of which mode to use in meeting the demand should instead be seen as a choice of production technology. Since the different transport modes all exhibit different cost characteristics overall efficiency entails

\footnotetext{
${ }^{3}$ As previously discussed, the PTAs makes almost all decisions influencing the performance of the system and is therefore assumed to be the relevant decision-making unit. The operators do not decide on fares, frequency, routes, type of vehicles and could therefore not be considered as being the relevant DMU since they do not actually decide anything. This might change in the future as the new public transport regulations allow free entry for private operators from the beginning of 2012.

${ }^{4}$ One might argue that ideally, passenger kilometres would be the best measure but data on trip length is only available for some counties and in those cases only for a few years.
} 
choosing the appropriate mix of transport modes given the demand level. Choosing train as the main mode of transport if the demand level is low or using only busses on links where demand is very high is inefficient (see Tirachini et.al. 2010for a simulation of how cost efficiency of different modes is affected by volume) Therefore the appropriate measure of output is number of trips (or passenger kilometres).

Several functional forms have been applied in empirical studies of public transport costs. The two most commonly used are the Cobb-Douglas function (e.g. Dalen and Gomez-Lobo, 2003; Jørgensen et al., 1997; Lin et al., 2010) or the translog function (e.g. Piacenza, 2006; Cambini et al., 2007; Karlaftis, 2010; Sakai and Shoji, 2010). Cambini et al. (2007) provide an overview of work done before 2006. The translog function can be seen as a second-order approximation of an unknown function, while the Cobb-Douglas function can be considered to be a first-order approximation. The translog function is therefore often referred to as a flexible functional form since it can mimic the behaviour of any other function. The use of flexible functional forms therefore reduces (removes) the problem of deciding on a specific functional form for the cost relationship. Chambers (1988) provides a thorough discussion of cost functions and the use of flexible forms in applied analysis. A translog cost function for the Swedish PTAs will therefore be used. A further specification of equation (3) is:

$$
\begin{aligned}
& \ln C_{i, t}=\sum_{n=1}^{3} \beta_{n} \ln w_{i, t}^{n}+\beta_{q} \ln q_{i, t}+0.5 \sum_{n=1}^{3} \sum_{m=1}^{3} \beta_{n, m} \ln w_{i, t}^{n} \ln w_{i, t}^{m}+ \\
& \sum_{n=1}^{3} \beta_{q n} \ln q_{i, t} \ln w_{i, t}^{n}+\beta_{q q}\left(\ln q_{i, t}\right)^{2}+d_{i, t}+\varepsilon_{i}
\end{aligned}
$$

Imposing linear homogeneity in prices ${ }^{5}$ (thereby making sure that general price increases does not affect the analysis) yields:

$$
\begin{aligned}
& \ln y_{i, t}=\beta_{2} z_{i, t}^{2}+\beta_{3} z_{i, t}^{3}+\beta_{q} \ln q_{i, t}+\beta_{1,2} z_{i, t}^{1,2}+\beta_{1,3} z_{i, t}^{1,3}+ \\
& \beta_{2,3} z_{i, t}^{2,3}+\beta_{q, 2} z_{i, t}^{q, 2}+\beta_{q, 3} z_{i, t}^{q, 3}+\beta_{q q}\left(\ln q_{i, t}\right)^{2}+d_{i, t}+\varepsilon_{i}
\end{aligned}
$$

where:

$$
\begin{aligned}
& y_{i, t}=\ln C_{i, t}-\ln w_{i, t}^{1} \\
& z_{i, t}^{n}=\ln w_{i, t}^{n}-\ln w_{i, t}^{1} \\
& z_{i, t}^{n, m}=\ln w_{i, t}^{n} \ln w_{i, t}^{m}-0.5\left(\ln w_{i, t}^{n}\right)^{2}-0.5\left(\ln w_{i, t}^{m}\right)^{2} \\
& z_{i, t}^{q, n}=\ln q_{i, t}\left(\ln w_{i, t}^{n}-\ln w_{i, t}^{1}\right) \\
& { }^{5} C(a \cdot w, q)=a \cdot C(w, q)
\end{aligned}
$$


As it is reasonable to assume that the effectiveness of management of the PTAs has changed over time, the measure of inefficiency should be allowed to vary over time in order to capture this. Following Cornwell et al. (1990), the inefficiency measure will be:

$d_{i, t}=\theta_{i}^{0}+\theta_{i}^{1} t+\theta_{i}^{2} t^{2}$

where t reflects time. This will allow the level of inefficiency to vary between counties and over time. It will also allow for the ranking, in terms of efficiency, of a county to change over time. For further discussion of different methods of time-dependent inefficiency, see Coelli et al. (2005).

The costs required to produce a certain amount of output could also be affected by differences in the production environment. External factors such as demographics and geography are likely to affect the costs of producing a given level of output (e.g. Reifschneider and Stevenson, 1991). In order to account for some of these effects, the model will also include variables describing the level of urbanisation $\left(\mathrm{U}_{i, t}\right)$ in a county as well as the area of the county $\left(A_{i, t}\right)$. Letting

$B_{i, t}=\alpha_{1} \ln U_{i, t}+\alpha_{2} \ln A_{i, t}$

and inserting this in (4) gives the final cost function to be estimated:

$\ln y_{i, t}=B_{i, t}+\beta_{2} z_{i, t}^{2}+\beta_{3} z_{i, t}^{3}+\beta_{q} \ln q_{i, t}+\beta_{1,2} z_{i, t}^{1,2}+\beta_{1,3} z_{i, t}^{1,3}+$

$\beta_{2,3} z_{i, t}^{2,3}+\beta_{q, 2} z_{i, t}^{q, 2}+\beta_{q, 3} z_{i, t}^{q, 3}+\beta_{q q}\left(\ln q_{i, t}\right)^{2}+d_{i, t}+\varepsilon_{i}$

Defining cost efficiency $\left(\mathrm{CE}_{\mathrm{i}, \mathrm{t}}\right)$ of county $\mathrm{i}$, period $\mathrm{t}$, as the ratio of minimum cost to observed cost, it can be shown that (Coelli et al., 2005, Bogetoft and Otto, 2010)

$$
C E_{i, t}=\exp \left(d_{i, t}\right)
$$

Overall industry efficiency $\left(\mathrm{IE}_{t}\right)$ at period $t$ can then be defined as the average efficiency level for that time period (Coelli et al., 2005, Bogetoft and Otto, 2010). 


\section{Data and key statistics}

The study uses annual data from 26 Swedish counties from 1986 to 2009. Due to changes in the county structure and missing data, there were 530 usable observations. The data concerning patronage and costs were provided by the Swedish Public Transport Association (Svenska Lokaltrafikföreningen, SLTF), ${ }^{6}$ to which local transport authorities reported key statistics. Data on other variables were obtained from Statistics Sweden (SCB ${ }^{7}$.

Table 1 shows data on costs per passenger trip and the number of trips per person in 2009, together with the changes in the variables during the observed period. The change in costs is expressed in real terms using 2009 as the base year, i.e. they are corrected for inflation. The table also shows the level of subsidization in each county for 2009. (Note that the observation periods for counties marked with * or ${ }^{* *}$ are different.) It can be seen that the costs in 2009 varied substantially between counties, and that the lowest cost per trip is in the county of Stockholm, which contains the Swedish capital. Stockholm also exhibits the highest production volume in terms of trips per capita. The most expensive public transport trips are undertaken in the county of Kalmar where costs per trip were $282 \%$ higher than in Stockholm. The highest cost increase (228\%) occurred in Jämtland, whereas the costs in Stockholm only increased by $28 \%$. Given that these figures are in real terms, i.e. they are corrected for inflation; the cost increases are remarkably high. The variation in trips per person is also quite large, and it is interesting to note that travel demand has fallen in most counties.

\footnotetext{
${ }^{6}$ This body is currently named Svensk Kollektivtrafik. Since 2010 the responsibility to gather data on public transport operations falls to the governmental agency Transport Analysis and the data used in this study can be ordered from them. (www.trafa.se)

${ }^{7}$ www.scb.se
} 
Table 1. Key statistics on costs, travel demand and subsidization of public transport in Swedish counties for 2009, and changes during the observed period

\begin{tabular}{|c|c|c|c|c|c|}
\hline County & $\begin{array}{l}\text { Cost per } \\
\text { passenger }\end{array}$ & $\begin{array}{c}\Delta \text { Cost } \\
1986-2009 \\
(\%)\end{array}$ & $\begin{array}{l}\text { Trips per } \\
\text { person }\end{array}$ & $\begin{array}{c}\Delta \text { Trips per } \\
\text { person } \\
1986-2009 \\
(\%)\end{array}$ & $\begin{array}{c}\text { Degree of } \\
\text { subsidization }\end{array}$ \\
\hline Stockholm & 19.08 & 28 & 346 & 6.8 & 46 \\
\hline Uppsala & 37.90 & 153 & 81 & -44.7 & 43 \\
\hline Södermanland & 47.54 & 179 & 34 & -41.8 & 65 \\
\hline Östergötland & 34.85 & 188 & 62 & -53.4 & 59 \\
\hline Jönköping & 34.99 & 139 & 48 & -30.1 & 49 \\
\hline Kronoberg & 50.45 & 115 & 33 & -15 & 46 \\
\hline Kalmar & 72.86 & 189 & 29 & -41 & 64 \\
\hline Gotland & 44.43 & 64 & 20 & -13 & 75 \\
\hline Blekinge & 33.39 & 52 & 50 & 13 & 49 \\
\hline Kristianstad ${ }^{*}$ & 27.40 & 53 & 27 & -41 & \\
\hline Malmöhus* & 16.89 & 20 & 72 & -34 & \\
\hline Skåne ${ }^{\star *}$ & 24.39 & 21 & 111 & 91 & 38 \\
\hline Halland & 37.32 & 122 & 42 & 3 & 39 \\
\hline Älvsborg* & 23.52 & 25 & 49 & 1 & \\
\hline Skaraborg* & 36.78 & 60 & 32 & -18 & \\
\hline \multicolumn{6}{|l|}{ Västra } \\
\hline Götaland** & 23.23 & 30 & 141 & 24 & 53 \\
\hline Värmland & 40.12 & 110 & 45 & 0.1 & 54 \\
\hline Örebro & 33.88 & 99 & 44 & -31 & 59 \\
\hline Västmanland & 37.87 & 141 & 34 & -38 & 57 \\
\hline Dalarna & 32.64 & 59 & 49 & -9 & 47 \\
\hline Gävleborg & 39.34 & 57 & 45 & -20 & 54 \\
\hline Västernorrland & 33.80 & 50 & 39 & -34 & 58 \\
\hline Jämtland & 48.04 & 228 & 43 & -68 & 53 \\
\hline Västerbotten & 56.83 & 66 & 36 & -26 & 49 \\
\hline Norrbotten & 56.09 & 67 & 34 & -14 & 48 \\
\hline
\end{tabular}

In the early 90:s electronic counting systems were introduced, replacing manual counting as a means to gather data on patronage. This might have improved the quality of data but there is no evidence that there is systematic differences before and after this occurred. (I.e. manual counting did not systematically over- or understate the number of trips made) There are of course always potential problems when comparing data over long periods of time but there have been no changes in how the data was defined over the observed time period. The proportion of different modes of transport used have changed somewhat (even though the between county variations are much higher) but as mentioned before, the choice of how to transport the passengers can be seen as a decision (a choice of production technology) affecting efficiency. Data on the proportion of different modes are available on county level for $2006-2009$ but before that it is only reported as an national aggregate. Table 2 show the proportion of trips made by bus in each county. 
Table 2. The proportion of local/regional public transport trips made by bus in 2009.

\begin{tabular}{|c|c|c|c|}
\hline County & Proportion bus (\%) & County & Proportion Bus (\%) \\
\hline Stockholm & 40 & Västra Götaland & 45 \\
\hline Uppsala & 85 & Värmland & 93 \\
\hline Södermanland & 100 & Örebro & 95 \\
\hline Östergötland & 77 & Västmanland & 92 \\
\hline Jönköping & 90 & Dalarna & 96 \\
\hline Kronoberg & 89 & Gävleborg & 94 \\
\hline Kalmar & 100 & Västernorrland & 100 \\
\hline Gotland & 100 & Jämtland & 100 \\
\hline Blekinge & 78 & Västerbotten & 100 \\
\hline Skåne & 75 & Norrbotten & 100 \\
\hline Halland & 67 & & \\
\hline
\end{tabular}

It is also important to point out that special transport services and school transports are not included in the data. ${ }^{8}$

\footnotetext{
${ }^{8}$ Some school children travel by regular public transport using travel cards paid for by the municipality, they are included in the data on number of passengers and also affect costs.
} 


\section{Results}

The results from the estimation ${ }^{9}$ of equation (6) excluding the individual, time dependent county effects (due to their number), can be seen in Table 3. The first order terms, as well as most of the other variables, are statistically significant.

Table 3. Results from estimation of equation (5)

\begin{tabular}{lcccc}
\hline \hline Variable & Coefficient & Std. Error & t-Statistic & Prob. \\
\hline \hline$z^{2}$ & 18.08308 & 0.990408 & 18.25821 & 0.0000 \\
$z^{3}$ & 0.148027 & 0.028305 & 5.229683 & 0.0000 \\
$\operatorname{lnq}$ & 0.426338 & 0.166428 & 2.561703 & 0.0107 \\
$z^{1,2}$ & -2.035401 & 0.125872 & -16.17042 & 0.0000 \\
$z^{1,3}$ & -0.004717 & 0.002999 & -1.572804 & 0.1165 \\
$z^{2,3}$ & 0.009758 & 0.002920 & 3.342141 & 0.0009 \\
$z^{q, 2}$ & -0.117073 & 0.001654 & -70.78921 & 0.0000 \\
$z^{q, 3}$ & -0.004716 & 0.000614 & -7.677283 & 0.0000 \\
$\operatorname{lnq}{ }^{2}$ & -0.013858 & 0.005146 & -2.693146 & 0.0073 \\
$\ln U$ & -0.068828 & 0.033912 & -2.029587 & 0.0430 \\
$\ln A$ & 0.125619 & 0.080283 & 1.564705 & 0.1184 \\
\hline \hline
\end{tabular}

Table 3 shows that the degree of urbanisation also has a negative impact on the cost level, which is to be expected since it is reasonable to assume that it is less costly to provide public transport where density of demand is high.

Efficiency levels were calculated for the individual counties as well as for the entire industry using the aforementioned definitions of efficiency (equation 7). The rather striking change in efficiency is shown in Figure 2. It appears that the efficiency level of the industry has been falling throughout the observed period.

\footnotetext{
${ }^{9}$ The estimation was performed in EVIEWS.

${ }^{10} \mathrm{i}$ and $\mathrm{t}$ indices are left out.
} 


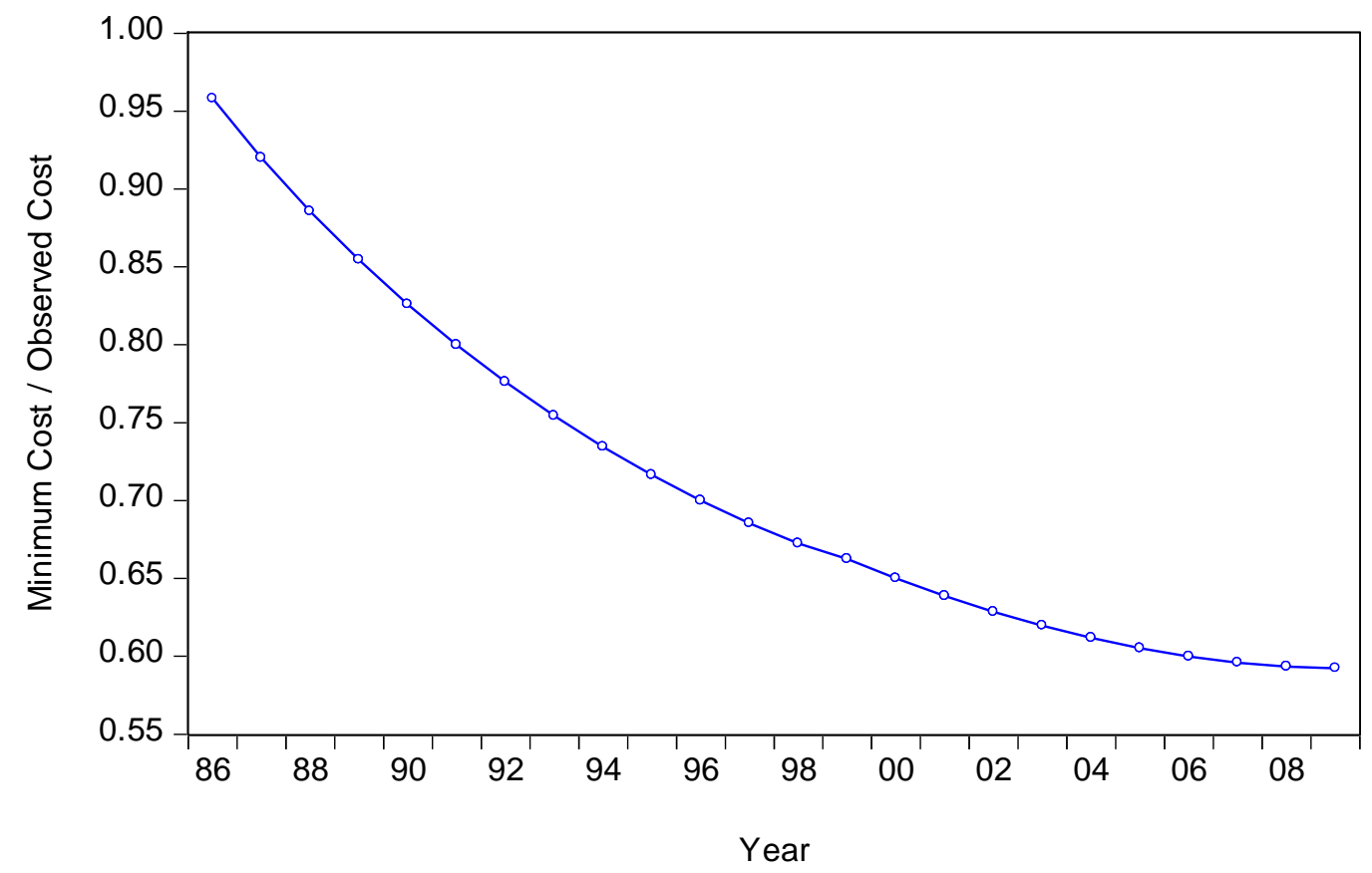

Figure 2. The change in overall (cost) efficiency of the local/regional public transport industry over time

Tables 4 to 6 show the estimated efficiency of Swedish public transport operators and their rank in terms of efficiency for different time periods. The time periods are arbitrarily chosen in order to illustrate the general tendency. Choosing five year (or smaller) intervals do not change the overall picture. ${ }^{11}$

\footnotetext{
${ }^{11}$ It is possible to provide a figure like figure 1 for each county but this is not done since it would require a lot of space and does not change the conclusions.
} 
Table 4. Average cost efficiency 1986-1989

\begin{tabular}{|c|c|c|}
\hline County & Rank & Cost Efficiency \\
\hline Kronoberg & 1 & 0.981 \\
\hline Halland & 2 & 0.970 \\
\hline Jönköping & 3 & 0.968 \\
\hline Blekinge & 4 & 0.964 \\
\hline Jämtland & 5 & 0.947 \\
\hline Stockholm & 6 & 0.937 \\
\hline Skaraborg & 7 & 0.934 \\
\hline Södermanland & 8 & 0.934 \\
\hline Kalmar & 9 & 0.931 \\
\hline Dalarna & 10 & 0.930 \\
\hline Östergötland & 11 & 0.930 \\
\hline Älvsborg & 12 & 0.923 \\
\hline Värmland & 13 & 0.923 \\
\hline Uppsala & 14 & 0.903 \\
\hline Västernorrland & 15 & 0.902 \\
\hline Kristianstad & 16 & 0.891 \\
\hline Västmanland & 17 & 0.889 \\
\hline Gävleborg & 18 & 0.877 \\
\hline Örebro & 19 & 0.874 \\
\hline Norrbotten & 20 & 0.820 \\
\hline Västerbotten & 21 & 0.819 \\
\hline Malmöhus & 22 & 0.782 \\
\hline Gotland & 23 & 0.776 \\
\hline
\end{tabular}

From Table 4 one can see that the most efficient PTA during the eighties was Kronoberg, followed by Halland and Jönköping. It is interesting to note that in terms of costs per passenger only, Kronoberg ranked $19^{\text {th }}$ for this period. On the other hand, the county of Uppsala, ranking $2^{\text {nd }}$ in terms of costs per passenger, is ranked $14^{\text {th }}$ in efficiency. The most surprising observation is perhaps that a majority of the counties appear to operate on an efficiency level above $90 \%$; the average industry efficiency for the period being $85.7 \%$.

Table 5 shows the average efficiency levels for the nineties as well as the county ranking and the corresponding ranking for the eighties. The average efficiency level for the time period has fallen to $73 \%$. Kronoberg is still ranked number one, but the county of Blekinge has taken second place. Although there are changes in the ranking of counties, these are rather small. 
Table 5. Average cost efficiency 1990 - 1999 (previous ranking in parenthesis)

\begin{tabular}{|c|c|c|}
\hline County & Rank & Cost Efficiency \\
\hline Kronoberg & $1(1)$ & 0.900 \\
\hline Blekinge & $2(4)$ & 0.889 \\
\hline Halland & $3(2)$ & 0.858 \\
\hline Jönköping & $4(3)$ & 0.830 \\
\hline Jämtland & $5(5)$ & 0.823 \\
\hline Stockholm & $6(6)$ & 0.795 \\
\hline Dalarna & $7(10)$ & 0.791 \\
\hline Södermanland & $8(8)$ & 0.774 \\
\hline Älvsborg & $9(12)$ & 0.769 \\
\hline Östergötland & $10(11)$ & 0.762 \\
\hline Kalmar & $11(9)$ & 0.759 \\
\hline Västernorrland & $12(15)$ & 0.748 \\
\hline Skaraborg & $13(7)$ & 0.738 \\
\hline Värmland & $14(13)$ & 0.735 \\
\hline Västmanland & $15(17)$ & 0.728 \\
\hline Uppsala & $16(14)$ & 0.703 \\
\hline Örebro & $17(19)$ & 0.670 \\
\hline Gävleborg & $18(18)$ & 0.666 \\
\hline Kristianstad & 19(16) & 0.654 \\
\hline Malmöhus & $20(22)$ & 0.646 \\
\hline Norrbotten & $21(20)$ & 0.565 \\
\hline Västerbotten & $22(21)$ & 0.556 \\
\hline Gotland & $23(23)$ & 0.508 \\
\hline
\end{tabular}

Turning to Table 6, showing the efficiency levels for the last decade (2000-2009), there have been some noteworthy changes. Västmanland and Västernorrland have both climbed rather high in the rankings from previously low positions, while Jönköping has fallen to the middle. The average industry efficiency during the period is $61.4 \%$. 
Table 6. Average cost efficiency $2000-2009$ (previous rankings in parenthesis)

\begin{tabular}{|c|c|c|}
\hline County & Rank & $\begin{array}{l}\text { Cost } \\
\text { Efficiency }\end{array}$ \\
\hline Blekinge & $1(2,4)$ & 0.833 \\
\hline Kronoberg & $2(1,1)$ & 0.737 \\
\hline Västmanland & $3(15,17)$ & 0.736 \\
\hline Västernorrland & $4(12,15)$ & 0.724 \\
\hline Jämtland & $5(5,5)$ & 0.694 \\
\hline Dalarna & $6(7,10)$ & 0.684 \\
\hline Halland & $7(3,2)$ & 0.661 \\
\hline Stockholm & $8(6,6)$ & 0.653 \\
\hline Älvsborg & $9(9,12)$ & 0.651 \\
\hline Södermanland & $10(8,8)$ & 0.592 \\
\hline Örebro & $11(17,19)$ & 0.591 \\
\hline Jönköping & $12(4,3)$ & 0.578 \\
\hline Östergötland & $13(10,11)$ & 0.574 \\
\hline Gotland & $14(23,23)$ & 0.561 \\
\hline Gävleborg & $15(18,18)$ & 0.556 \\
\hline Kalmar & $16(11,9)$ & 0.555 \\
\hline Västra Götaland & 17 (NA) & 0.548 \\
\hline Skåne & 18 (NA) & 0.546 \\
\hline Uppsala & $19(16,14)$ & 0.532 \\
\hline Värmland & $20(14,13)$ & 0.522 \\
\hline Norrbotten & $21(21,20)$ & 0.507 \\
\hline Västerbotten & $22(22,21)$ & 0.471 \\
\hline
\end{tabular}

The rankings in Table 6 can also be compared to those presented by Söderberg (2009) who performed efficiency analysis of public transport authorities in Sweden for the years 2002 to 2006. Söderberg (2009) used $D_{E A}{ }^{12}$ where output was defined in terms of different qualitative indices measured in surveys among users of public transport. In his study, Västmanland was found to be the most efficient county while Örebro and Halland placed second and third. Västmanland places high in both studies, as does Halland. Örebro appears less efficient according to this study than in Söderberg (2009). According to Söderberg (2009) the bottom five consisted of (starting with the least efficient) Jämtland, Uppsala, Stockholm, Västerbotten and Västra Götaland. Jämtland and Stockholm perform better according to the present study, while the others perform relatively poorly in both studies. Skåne, which is often portrayed as a success story, places fifth from the bottom in the present study, while being the fourth most efficient in Söderberg (2009). When considering the results of Söderberg (2009) it is important to acknowledge that by using a output variable

\footnotetext{
${ }^{12}$ See e.g. Färe et al. (1994), Coelli et al. (2005) or Bogetoft and Otto (2010) for more on DEA. The latter two include comparisons to SFA.
} 
reflecting the views of people already using public transport it reflects the PTAs efficiency in satisfying there present costumers that, as the system works today, are captive riders. Using number of passengers, as in this study, give a better reflection of their efficiency in providing public transport to large numbers and therefore be a potential alternative to car use.

\section{Explaining the development}

Given such striking negative development one has to wonder; how could this have happened? Cost efficiency could be decomposed into technical efficiency (TE) and allocative efficiency AE so that (e.g. Coelli et.al. (2005):

$$
\mathrm{CE}=\mathrm{CTE} \cdot \mathrm{CAE}
$$

Or if constant returns to scale is assumed:

$\mathrm{CE}=\mathrm{TE} \cdot \mathrm{AE}$

In order to be cost efficient, a producer needs to choose the right mix of inputs, i.e. achieve allocative efficiency, as well as use the inputs in a technically efficient manner, i.e. achieve technical efficiency. (e.g. Bogetoft and Otto, 2011) Therefore changes in cost efficiency could be sought in either change in technical efficiency or allocative efficiency. Due to lack of data on the actual amounts of inputs used by the counties it is not possible to perform a formal decomposition but it is possible to discuss what might be viable candidates as explanations for the development. ${ }^{13}$

Looking at what important changes that has taken place during the observed time period two major candidates for explaining the development emerges. The first is the increased emphasis on accessibility of the public transport network. This has been an ongoing process since 1979 when a new law required that the public transport system should be made available to people with disabilities (this includes the elderly that may have decreased mobility due to age). According to the law, the public transport system was to be made accessible and the changes were to be implemented "at the rate, and to the extent possible given the technical and economic limitations facing the public transport authorities" ${ }^{14}$. (Act 1979:558) In practice, significant changes in accessibility began taking place in the 1990:s and in 2000 the Swedish parliament voted yes to a national Plan of action for disability policy that further stressed the importance of accessibility in the transport system. (Act 1999/2000:79). Besides having vehicles with low floors, space for wheelchairs and easily accessible seats etc., it has become common practice to define accessibility to the public transport system in terms of having less than 400 meters to the nearest bus stop. It can be seen that the proportion of urban population having less than 200 meters to the closest access point for public transport (bus, or tram stop) have increased by $12 \%$ between 1980 and 1995. (Reneland, 1998, 2000) There is no reason to think that this development has slowed down since then, national as well as local policy makers stress the fact that

\footnotetext{
${ }^{13}$ Bogetoft and Otto(2011) points out that in practical analysis the choice of efficiency measure often has to be governed by the available data.

${ }^{14}$ Translation from Swedish
}

Page 16 of 23 
accessibility needs to be increased further and, in fact, many municipalities now include in their local regulations that no one living in urban areas should have more than 400 meters to a bus stop. (Ljungberg, 2007) In addition to this, there has been an increase in the safety and environmental demands on busses used for public transport. There is now a requirement that busses used outside of urban areas should have seatbelts and in many counties bio-fuel are used in urban traffic.

This is not to say that this development is without benefits, clearly making society accessible to all, caring for the environment and increasing safety are important goals but it is also important to remember that no choice is without cost. If transport planners are required to plan the public transport system with restrictions in the placing of stops, costs per passenger will increase. Less direct or more routes have to be used in order to transport the passengers. In both cases, costs will increase and if less direct routes are used, increased time costs will result in falling demand and hence higher cost per passenger. Making the system more accessible to the disabled and old might also increase boarding times ${ }^{15}$ resulting in a loss of other passengers due to increased time costs. In addition to this, imposing restrictions on the type of fuel used and increased safety regulations will also increase costs.

Another development that might be part of the explanation for the negative development for cost efficiency is the shift in production technology from bus to rail. As previously argued, the efficient combination of transport modes used for transporting passengers varies by the volume demanded. At a low demand level, bus is more cost efficient while at high demand levels heavy train is the most efficient option with light rail and BRT options being efficient in between. (e.g. Tirachini et.al. 2010) Figure 3 show that the public transport system in Sweden has decreased its reliance on bus, and instead shifted some of the traffic to rail. Parallel to this development, demand has fallen in most counties (see table 1.) and it is therefore unlikely that rail is a more efficient choice of mode now than it was in the $80: \mathrm{s}$ or 90:s. ${ }^{16}$ In addition to this, it should also be mentioned that the demand levels in the sparsely populated country of Sweden are quite low outside of the three areas in which the three largest cities (Stockholm, Gothenburg and Malmö) is located. If this is so, why has rail based solutions become more common? It can be seen that rail is often advocated by politicians and is often associated with an idea of environmental friendliness. (See e.g. Nilsson and Pyddoke, 2009 for a discussion on the perception of train as being environmentally friendly)

\footnotetext{
${ }^{15}$ Drivers are often instructed that they should, if necessary, assit people in boarding which increase time costs even further.

${ }^{16}$ I might be good to remind the reader that this is a study of regional and local travel and not long distance.
} 


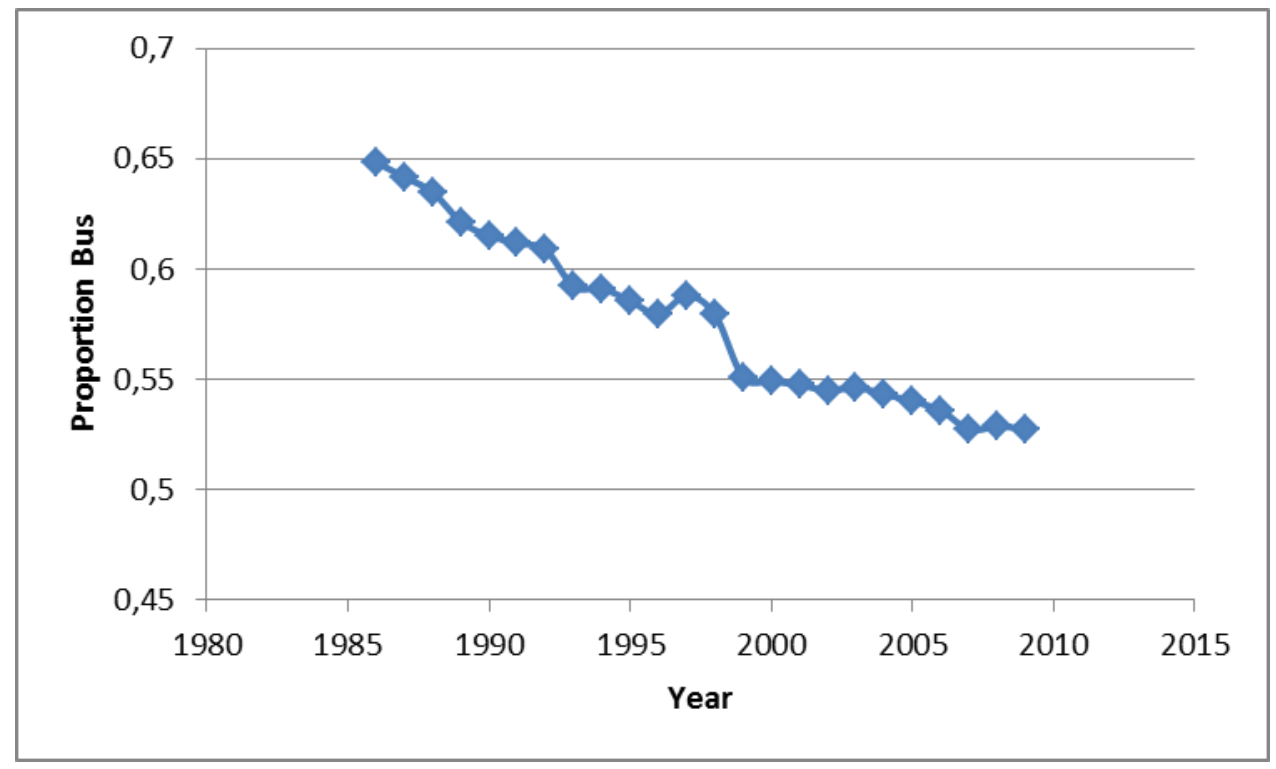

Figure 3. The proportion of Swedish local/regional public transport trips made by bus

Therefore, in terms of (8), it is suggested that at least part of the observed decrease in cost efficiency could be attributed to changes in technical efficiency. Technical efficiency should in this context be understood broadly. Given a certain demand level, choosing the most efficient way of transporting those passengers include choosing the correct mode of transport as well as the planning the most efficient public transport network. It might therefore be argued that the increased emphasis on accessibility has reduced the efficiency of the system, if production is measured in terms of the number of passengers transported, as it requires less efficient routing and longer boarding times. At the same time the increased emphasis on using rail despite low, and falling, demand levels would is also likely to have decreased the efficiency of the system.

So far the discussion has focused on the question of technical efficiency, depending on your definition of capital the choice of employing more trains and less busses in the system could also be seen as a change in the mixture of inputs in which case the decreased cost efficiency could be attributed to reduced allocative efficiency as well.

\section{Conclusions}

The analysis has shown that the average industry efficiency has decreased substantially during the observed period (1986-2009). Defined as the ratio of minimum cost to observed cost, the average industry efficiency during the eighties was found to be $85.7 \%$, while the corresponding figure for 2000-2009 was $61.4 \%$. Cost efficiency has fallen in all counties but in some more than others, resulting in changes in the relative efficiency, i.e. the efficiency ranking of the counties. These results are also reflected in the figures presented in Table 1, which shows increases in the real costs per trip vary from $28 \%$ to $228 \%$ between 1986 and 2009. 
The reasons for the decreasing efficiency in the industry are not formally explored due to lack of sufficient data. However, a few possible explanations are offered in the previous section. First of all, there has been an on-going development in which different kinds of restrictions are imposed on the network design and on the vehicles that are to be used. Increased emphasis on making the public transport system more accessible to the disabled and the elderly have put restraints on where bus stops can be placed since most municipalities now require short walking distances for all their inhabitants. The use of low floor busses and giving assistance to people boarding will increase time cost and reduce patronage. Costs might also be increased due to higher environmental and safety standards. It is important to stress that this is not necessarily bad as long as they are chosen as part of a conscious strategy for public transport. Such requirements will increase the costs and unless more money is spent on public transport the service quality for other users are likely to fall. (Even though they might gain a cleaner environment, unless those leaving public transport start using the car instead) This illustrates the problem of introducing new goals and requirements without providing additional funding.

The other potential explanation offered is a shift in production technology. A larger proportion of the production (the transportation of passengers) is now undertaken using train instead of bus. This is despite the fact that patronage is falling and train is more efficient in situations where demand is high and bus is more efficient when demand is lower. Such shift will also increase costs. An important point that is sometimes forgotten in practical transport policy is that no single transport mode can be considered best in all contexts.

Another thing that might be interesting to mention is that in most current discussions on public transport in Sweden, the county of Skåne is portrayed as a success story and a role model for others to take after. (e.g. the report on which the new public transport regulations from 2012 is founded, SOU, 2009:39) This might partly be due to the massive increase in patronage since the county (region) was formed in 1999. However, in this study Skåne place in the bottom of the efficiency ranking. The reason for this is that, given their high levels of patronage, large population and high degree of urbanization, they should be able to produce at an even lower cost.

Another point of interest could be seen by comparing figure 1 and figure 2 . It is apparent that the introduction of competitive tendering has not been enough to compensate for the negative effects of other developments although the situation might have been worse without it. 


\section{References}

Act 1978:438

Act 1979:558

Act $1999 / 2000: 79$

Alexandersson, G. 2010. The Accidental Deregulation - Essays on Reforms in the Swedish Bus and Railway Industries 1979-2009. PhD Thesis, Stockholm School of Economics

Alexandersson, G. Hulten, S. Fölster, S. 1998. The Effects of Competition in Swedish Local Bus services. Journal of Transport Economics and policy 32, 203-219

Alexandersson, G. Pyddoke, R. 2003. Bus Deregulation in Sweden Revisited: Experiences from 15 Years of Competitive Tendering, Paper presented at the $8^{\text {th }}$ international conference on competition and ownership in land passenger transport, Thredbo 8. Rio de Janeiro, Brazil

Barbot, C., Costa, A., Sochira, E., 2008 Airlines performance in the new market context: A comparative productivity and efficiency analysis. Journal of Air Transport Management 14, 270-274.

Barros, C.P., Peypoch, N., 2009. An evaluation of European airlines' operational performance. International Journal of Production Economics 122, 525-533.

Bhadra, D., 2009. Race to the bottom or swimming upstream: Performance analysis of US airlines. Journal of Air Transport Management 15, 227-235.

Bogetoft, P., Otto, L., 2010. Benchmarking with DEA, SFA, and R, Springer, New York

Buchanan J.M., Tullock, G., 1962. The Calculus of Consent: Logical Foundations of Constitutional Democracy, University of Michigan Press, Ann Arbor, Michigan, USA.

Button, K., 2010. Transport Economics, $3^{\text {rd }}$ ed. Edward Elgar, Cheltenham.

Cambini, C., Piacenza, M., Vannoni, D., 2007. Restructuring public transit systems: Evidence on cost properties from medium and large-sized companies. Review of Industrial Organization 31, 183-203.

Chambers, R.G., 1988. Applied Production Analysis: A dual approach. Cambridge University Press, Cambridge.

Cornwell, C., Smith, P., Sickles, R.C., 1990. Production frontiers with cross-sectional and time-series variation in efficiency levels. Journal of Econometrics 46, 185-200. 
Coelli, T., Perelman, S., 1999. A comparison of parametric and non-parametric distance functions: With application to European railways. European Journal of Operational Research 117, 326-339.

Coelli, T.J., Prasada Rao, D.S., O’Donnell, C.J., Battese, G.E., 2005. An Introduction to Efficiency and Productivity Analysis, Springer, New York

Dalen, D.M., Gomez-Lobo, A., 2003. Yardsticks on the road: Regulatory contracts and cost efficiency in the Norwegian bus industry. Transportation 30, 371-386.

De Borger, B., Kerstens, B.K., Costa, A., 2002. Public transport performance: what does one learn from frontier studies?, Transport Reviews 22, 1-38.

Färe, R., Grosskopf, S., Lovell, C.A., 1994. Production Frontiers, Cambridge University Press, Cambridge.

Hansson, L., 2010a. Public procurement at the local government level: Actor roles, discretion and constraints in the implementation of public transport goals. PhD thesis, Linköping University, Sweden.

Hansson, L., 2010b. Solving procurement problems in public transport: Examining multiprincipal roles in relation to effective control mechanisms. Research in Transportation Economics 29, 124-132.

Hansson, L. 2011. The tactics behind public transport procurements: an integrated actor approach. European Transport Research Review. 3, 197-209

Hirschhausen, C., Cullman, A., 2010. A nonparametric efficiency analysis of German public transport companies. Transportation Research Part E, 46, 436-445.

Jansson, J.O., 1984. Transport System Optimization and Pricing, John Wiley, New York.

Jansson, K. Wallin, B. (1991) Deregulation of Public Transport in Sweden. Journal of Transport Economics and Policy. 97-107

Jørgensen, F., Pedersen, P.A., Volden, R., 1997. Estimating the inefficiency in the Norwegian bus industry from stochastic cost frontier models. Transportation 24, 421-433.

Karlaftis, M., 2010. Ownership and competition in European transit: Assessing efficiency. Transportmetrica 6, 143-160. 
Lin, E., Lan, L., Chiu, A., 2011. Measuring transport efficiency with adjustment of accidents: Case of Tapei bus transit. Transportmetrica 6, 79-96.

Ljungberg, A., 2010. Local Public Transport on the basis of Social Economic Criteria. Research in Transportation Economics 29, 339-345.

Macario, R. (2001) Managing and assessing regulatory evolution in local public transport operations in Europe, Paper presented at the $7^{\text {th }}$ international conference on competition and ownership in land passenger transport, Thredbo 7. Molde, Norway

Merkert, R., Smith, A., Nash, C., 2010. Benchmarking of train operating firms: A transaction cost efficiency analysis. Transportation Planning and Technology 33, 35-53

Merkert, R., Hensher, D.A., 2011. The impact of strategic management and fleet planning on airline efficiency: A random effects Tobit model based on DEA efficiency scores. Transportation Research Part A 45, 686-695.

Mueller, D., 2003. Public Choice III, Cambridge University Press, Cambridge.

Nash, C. A., 1982. Economics of public transport. Longman, London.

Nilsson, J-E. Pyddoke, R. (2009) Höghastighetsjärnvägar - ett klimatpolitiskt stickspår, VTI report 655 .

Niskanen, W.A., 1971. Bureaucracy and Representative Government, Aldine, Chicago.

Odeck, J., 2008. The effect of mergers on the efficiency and productivity of public transport services. Transportation Research Part A 42, 696-708.

Ouellette, P., Petit, P., Tessier-Parent, L.-P., Vigeant, S., 2010. Introducing regulation in the measurement of efficiency, with application to the Canadian air carrier industry. European Journal of Operational Research 200, 216-226.

Oum, T.H., Walters, W.G., 1996. Recent developments in cost function research in transportation. Logistics and Transportation Review 32, 423-463.

Piacenza, M., 2006. Regulatory contracts and cost efficiency: Stochastic frontier evidence from Italian local public transport. Journal of Production Analysis 25, 257-277.

Reifschneider, D., Stevenson, R., 1991. Systematic Departures from the Frontier: A Framework for the Analysis of Firm. International Economic Review32, 715-23

Reneland, M. 1998. Kollektivtrafikens Effektivitet:GIS-Projektet Tillgänglighet i Svenska städer. Rapport Stads- och trafikplanering, Chalmers University of Technology, Gothenburg, Sweden, 1400-1888 
Reneland, M. 2000. The GIS Research Project - Accessiability in Swedish Towns 1980 to 1995, Research Report, Chalmers University of Technology, Gothenburg, Sweden

Rivera-Trujillo, C., 2005. Measuring technical efficiency in North and South American railways using a stochastic frontier model: An international comparison, In: Hensher, D.A. (Ed.) Competition and Ownership in Land Passenger Transport Elsevier, pp. 423-441.

Small, K., Parry, I., 2009. Should urban transit subsidies be reduced?, American Economic Review 99, 700-724.

Sakai, H., Shoji, K., 2010. The effect of governmental subsidies and contractual model on the publicly-owned bus sector in Japan. Research in Transportation Economics 29, 60-71.

Sonesson, T. 2006. Optimal System of Subsidization for Local Public Transport. VINNOVA report 2006:9

SOU 2009. En ny kollektivtrafiklag. SOU 2009:39, Fritzes förlag, Stockholm

Söderberg, M., 2009. A broad performance benchmark based on citizens' preferences: The case of Swedish public transportation. Annals of Public and Cooperative Economics 80, 579-603.

Tirachini, A. Hensher, D. Jara-Diaz, S. 2010. Comparing operator and user costs of light rail, heavy rail and bus rapid transit over a radial public transport network. Research in Transportation Economics 29, 231-242 